\title{
EFFECT OF SEED COATING MATERIAL AND STORAGE CONTAINERS ON GERMINATION AND SEEDLING VIGOUR OF SOYBEAN (Glycine max L.)
}

\author{
Omvati Verma*1 $^{* 1}$ and R. S. Verma ${ }^{2}$ \\ Department of Agronomy, College of Agriculture, G.B. Pant University of Agriculture and Technology, \\ Pantnagar-263145, Uttarakhand, India
}

\begin{abstract}
A laboratory experiment was conducted to evaluate the effect of different seed coating materials and storage containers on germination, seedling vigour and suitability of packaging material for soybean seed. Seed of soybean varietyPS1024 was used for coating purpose with 6 coating treatments viz., $T_{0}$ (control), $T_{1}$ (Polymer coating i.e. Polykote @ $3 \mathrm{ml} \mathrm{kg}^{-1}$ of seed diluted with $5 \mathrm{ml}$ of water), $\mathrm{T}_{2}$ (Flowable Thiram i.e. Royal flow 40 SC @ $2.4 \mathrm{ml} \mathrm{kg}^{-1}$ of seed), $\mathrm{T}_{3}\left(\mathrm{~T}_{1}+\mathrm{T}_{2}\right), \mathrm{T}_{4}$ (Vitavax 200 i.e.thiram $37.5 \%$ and carboxyl 37.5\% @ $2 \mathrm{~g} \mathrm{~kg}^{-1}$ of seed and $\mathrm{T}_{5}\left(\mathrm{~T}_{1}+\mathrm{T}_{4}\right)$. The coated seeds were stored in two kinds of containers i.e. jute canvas bag, high density poly ethylene (HDPE) non- laminated bag and bimonthly observation on germination and seedling vigour were recorded. After $8^{\text {th }}$ month of storage, germination and vigour index in polythene bag stored seeds were significantly higher than the seed stored in cloth bag. Among seed coating treatments, maximum \%germination was recorded in polymer coating@ @ $3 \mathrm{~m} \mathrm{~kg}^{-1}$ followed by vitavax $200 @ 2 \mathrm{~g} \mathrm{~kg}^{-1}$ of seed treatment $\left(T_{5}\right)$ which was significantly higher than rest of the coated treatment including untreated control seeds $\left(T_{0}\right)$. Similarly, maximum seed vigour index was observed in $T_{5}$ and minimum vigor index was recorded with $T_{0}$ (untreated control).
\end{abstract}

Key words: Fungicide treatment, Polymer, Seed coating, Soybean, Storage container

\section{INTRODUCTION}

Quality seed is the basis for profitable production and expansion of soybean crop. Loss of viability and vigour under high temperature and humid conditions is a common phenomenon in many crop seeds but it is well marked in soybean (Burris,

\footnotetext{
*Corresponding author: email: dr_omvati@ rediffmail.com

${ }^{1}$ Junior Research Officer

${ }^{2}$ Ex. Professor
}

Received: 20.02.2014 
1980; Tatipata, 2009). Proper seed treatment with fungicide will improve the germination of poor quality seed if the low quality is due to fungal infection. A fungicide treatment also protects the seeds and young seedlings from many seed borne and soil borne pathogens (Taylor et al., 1998).

Polymer coating is used in pharmaceutical and confectionary industries for uniform application of material to seeds. The film formulation consists of mixture of polymer, plasticizer and colorants that are commercially available as ready to use as liquids (Ni, 1997).Polymer coating acts as a temperature switch and protective coating by regulating intake of water by seed coat, until the soil has warmed to a predetermined temperature. It enables accurate and even dose of chemicals and reduces chemical wastage. It also provides resistance against mechanical damage in the seed drill. Thus improves the appearance and quality of treated seeds. Seed coating materials were reported to improve the germination and increase the seedling emergence at changing soil moisture regime especially in the sub-optimal range (Scott., 1989; Sherin and Susan John., 2003). It is due to increase in the rate of moisture imbibition where the fine particles in the coating act as a 'wick' or moisture attracting material or perhaps to improve seed soil contact. Coating with hydrophilic polymer regulates the rate of water uptake, reduce imbibition damage and improve the emergence of soybean seeds (Vanangamudi et al., 2003). Polymer coating makes sowing operation easier due to the smooth flow of seeds. Addition of colorants helps in visual monitoring of placement accuracy, enhance the appearance, marketability and consumer preference.

Soybean seeds lose viability within 3-4 months if the storage arrangement and the condition of seed are not proper (Sadjad, 1980). Types of container also regulate temperature, relative humidity and seed moisture contents. High temperature, relative humidity and moisture in the storage environment appear to be main factor involved in deterioration of seed quality. Maintenance of seed quality during storage period is important not only for crop production in the following year but also for the maintenance seeds because of their constant threat and of genetic erosion. In view of the above facts, the present research work was undertaken to evaluate the effect of different coating materials and storage container on germination and seedling vigour of stored soybean seed.

\section{MATERIALS AND METHODS}

A laboratory study was carried out at G. B. Pant University of Agriculture and Technology, Pantnagar,Uttarakhand (India). Breeder seeds of soybean (Glycine max L.) variety PS 1024 were used for coating purpose. It was collected from Breeder Seed Production Centre, Pantnagar. There were 6 coating treatments viz., $\mathrm{T}_{0}$ (control), $\mathrm{T}_{1}$ (Polymer coating i.e. Polykote @ $3 \mathrm{ml} \mathrm{kg}^{-1}$ of seed diluted with $5 \mathrm{ml}$ of water), $\mathrm{T}_{2}$ (FlowableThiram i.e., Royal flow $40 \mathrm{SC} @ 2.4 \mathrm{ml} \mathrm{kg}{ }^{-1}$ of seed), $\mathrm{T}_{3}\left(\mathrm{~T}_{1}+\right.$ $\mathrm{T}_{2}$ ), $\mathrm{T}_{4}$ (Vitavax 200 i.e. thiram $37.5 \%$ and carboxyl $37.5 \% @ 2 \mathrm{~g} \mathrm{~kg}^{-1}$ of seed and 
$\mathrm{T}_{5}\left(\mathrm{~T}_{1}+\mathrm{T}_{4}\right)$. Prior to coating initial seed moisture content, germination percentage, seedling dry weight, seedling vigour index and field emergence were recorded. After performing seed coating treatments increase in seed weight was recorded .Then seeds were stored at $8.0 \%$ moisture content in two types of containers viz., cloth bag (moisture pervious container) and 250-gauge polyethylene bag (moisture impervious container) under ambient storage condition. During storage, seed germination and seedling vigour were recorded at bimonthly to retain Indian Minimum Seed Certification Standard i.e. 70 per cent germination. For determining moisture content, five grams of ground and sieved seed sample was weighed from each treatment in three replications and kept in an oven maintained at $103^{\circ} \mathrm{C}$ temperature for a period of 18 hours (Government of India, Department of Agriculture and Cooperation, Ministry of Agriculture, 1993) .The moisture content of seeds was determined on wet weight basis. Standard germination test was conducted in four replications as per International Rules for Seed Testing (ISTA, 1993). At the end of the standard germination test, ten normal seedlings were randomly selected and kept in an oven at $80 \pm 2^{\circ} \mathrm{C}$ for 72 hours until the weight become constant for measuring seedling dry weight. Seedling vigour index was computed by multiplying germination into average seedling dry weight. Field emergence was recorded at the end of 4 months of storage. For recording field emergence 100 seeds in four replications were sown in the field and on eighth day number of seeds emerged were counted and field emergence per cent was calculated as per standard germination test (ISTA, 1993). Thus total 12 treatment combinations were analyzed in 2 factors RBD (first factor storage containers and second factor seed coating treatments) (Gomez and Gomez, 1984). Standard error of means (S. Em. \pm ) was computed and critical differences (C.D.) at $5 \%$ level of probability were worked out for comparing treatments in case of significant ' $F$ ' test.

\section{RESULTS AND DISCUSSION}

The data pertaining to germination (\%), seedling dry weight ( $\mathrm{mg} / \mathrm{seedling}$ ), vigour index , field emergence and moisture content as influenced by seed coating treatments and storage containers are presented in the Table 1 and in figures 1 and 2 . The results showed significant difference with respect to germination and vigour due to seed coating treatments and storage containers whereas seed coating treatments.

\section{Effect of seed coating materials}

Up to 6 months of storage, all the seed coating treatments of soybean seed showed germination above Minimum Seed certification Standard (MSCS) i.e. 70.0\% germination (Table 1), but at the end of the $8^{\text {th }}$ month of storage, polymer coating followed by vitavax $200 @ 2 \mathrm{~g} \mathrm{~kg}^{-1}$ of seed $\left(\mathrm{T}_{5=} \mathrm{T}_{1}+\mathrm{T}_{4}\right)$ resulted highest $(75.7 \%)$ germination which was significantly higher than rest of the coating treatments including control. The reason may be that the fine particles in the polymer coating act 
as a 'wick' or moisture attracting material. Coating with hydrophilic polymer regulates the rate of water uptake, reduce imbibition damage and improve the emergence of soybean seeds. Omar and Rahhal (1993) recorded that seed coating with thiram increased the percentage of seedling survival in soybean compared to untreated control. The lowest germination $(66.2 \%)$ was found in untreated control $\left(\mathrm{T}_{0}\right)$ which was below MSCS level. Polymer coating alone $\left(\mathrm{T}_{1}\right)$ also improved germination percentage of soybean seed. The value of germination per cent (71.2\%) was significantly higher than untreated control and lower to rest of the seed coating treatments. The polymer film may act as physical barrier, which has been reported to reduce the leaching of organic substances from the seed coverings and may restrict oxygen diffusion to the embryo (Vanangamudi et al., 2003). These results are in agreement with Chachalis and Smith, (2001) wherein they reported that soybean seed coating with polymer regulated the rate of water uptake, reduced imbibitional damage and improved the germination and seedling emergence in flooded soil condition. Wilson and Geneve (2004) also reported that corn seed coated with polymer and fungicide resulted higher germination (98.5\%), less number of abnormal seedlings compared to control $(89.0 \%$, During initial months of storage seedling vigour index of all the seed coating treatments was superior to that of control. Among different treatment combinations the seeds coated with polymer @ $3 \mathrm{ml} \mathrm{kg}^{-1}$ followed by vitavax $200 @ 2 \mathrm{~g} \mathrm{~kg}^{-1}$ of seed $\left(\mathrm{T}_{5}\right)$ treatment recorded significantly higher vigour index (9077) which was at par with Polymer + Flowable Thiram (Royal flow $40 \mathrm{SC}$ ) @ $2.4 \mathrm{ml} \mathrm{kg}^{-1}$ of seed treatment $\left(\mathrm{T}_{3}\right)$ at the end of storage. The lowest vigour index (7854) was noticed in untreated control seeds (Table1). It may be due to age induced decline in germination, decrease in dry matter accumulation in seedling and decrease in seedling dry weight. Similar findings were reported by Savitri et al. (1994) in sorghum and Savitri et al. (1998) in groundnut. Dadlani et al. (1992) recorded higher root length $(34.80 \mathrm{~mm})$, shoot length $(170.20 \mathrm{~mm})$ and dry weight of seedling $\left(52.80 \mathrm{mg}^{-1}\right.$ seedling $\left.{ }^{-1}\right)$ as compared to control $(33.63 \mathrm{~mm}, 147.60$ $\mathrm{mm}$ and $48.30 \mathrm{mg}$ seedling ${ }^{-1}$, respectively) when seeds of IR 20 coated with polymer. The field emergence differed significantly among different treatments. Significantly highest field emergence of $79.7 \%$ was recorded in polymer coating @ $3 \mathrm{ml} \mathrm{kg}^{-1}$ followed by vitavax $200 @ 2 \mathrm{~g} \mathrm{~kg}^{-1}$ of seed $\left(\mathrm{T}_{5}\right)$ which is $10.9 \%$ highest over control followed by 79.0 in Polymer + Flowable Thiram (Royal flow $40 \mathrm{SC}$ ) @ $2.4 \mathrm{ml} \mathrm{kg}^{-1}$ of seed $\left(\mathrm{T}_{3}\right)$ as compared to control $(71.0 \%)$ after 4 months of storage (Figure 2B). This decrease in the field emergence may be due to age induced deteriorative changes in cell and cell organells and germinative capacity of seed under natural soil conditions. These results are in conformity with the findings of Raj et al. (2002) in soybean.

\section{Effect of Storage Containers}

Higher moisture in seeds enhances seed deterioration, which ultimately reduces the planting value of seeds in the field (Justice and Bass, 1978; Vertucci and Roos, 1993). Preset study revealed that the moisture content of the seed increases with 
advancement of storage period. The fluctuation in seed moisture was more in seeds stored in cloth bag than polythene bag (Figure 1A). As seed is highly hygroscopic in nature; it absorbs moisture from air if it is stored in an environment where relative humidity is higher than seed moisture content (Harrington 1973). The relative humidity was above $75 \%$ throughout the storage period. For this reason, seeds absorbed moisture from the ambient air and tended to equilibrium with relative humidity. The rate of absorbance was higher in cloth bag because of cloth bags are moisture pervious container but polythene bags are moisture impervious. Similarly values of standard germination gradually declined with increase in storage period under both cloth bag and polythene bag with latter showing significantly higher values (Table 1). It was observed that upto sixth months of storage germination per cent was above MSCS Level in both the containers but with the increase in storage period it was decreased. At the end of $8^{\text {th }}$ month of storage, germination per cent in polythene bag was $74.3 \%$, which was significantly higher than the seed stored in cloth bag (68.7\%). The reduction in germination was higher in cloth bag in comparison to polythene bag. The seeds of cloth bag absorbed moisture from the surrounding atmosphere. Due to increase in moisture content of seeds, respiratory activity and other physiological activities of the stored seeds increased and the rate of deterioration in terms of formation of abnormal seedling and dead seeds increased. These results are in agreement with Monira et al. (2012) wherein they reported that the moisture content increased with advanced of storage period but the increasing rate was higher in the seeds of cloth bag. The shoot length, root length of seedling and seedling vigour was lowest at the end of storage in cloth bag. Rahman and Rahman (1997) also reported that the highest germination and lowest prevalence of fungi in the seeds stored in tin followed by polythene bag and cloth bag with polythene. Field emergence of soybean seeds was significantly higher in the seeds stored in polythene bag (79.6\%) than cloth bag (76.8\%) after four months of storage (Figure 1B).This may be due to ageing, which resulted in deterioration of seed resulting the decrease in the field emergence.

\section{CONCLUSION}

Polymer coating prior to fungicide seed treatment improve the efficacy of fungicide maintaining higher germination of soybean seed after storage. Among two types of containers, polythene bags were found superior for maintaining viability of soybean seed. Cloth bag is not safe for soybean seed storage for longer time because the rate of moisture migration was higher in cloth bag than polythene bag.

\section{ACKNOWLEDGEMENT}

Authors are thankful to Directorate of Seed Research, Mau for providing the financial assistance to conduct the experiment. The author acknowledged to Director Experiment Station and Head Department of Agronomy for providing necessary facilities during course of studies. 


\section{REFERENCES}

Burris, J.S. 1980.Maintenance of soybean seed quality in storage as influenced by moisture and genotype. Iowa State Journal of Research, 54:377-389

Chachalis, D. and Smith, M. L. 2001. Hydrophilic polymer application reduces imbibition rate and partially improve germination or emergence of soybean seedlings. Seed Science and Technology, 29(1): 91-98

Dadlani, M., Shenoy, V. V. and Seshu, V.1992. Seed coating to improve stand establishment in rice. Seed Science and Technology, 20: 307-3217

Gomez, K.A. and Gomez, A.A. 1984. Statistical procedures for agricultural research. $2^{\text {nd }}$ Ed. John Wiley \& Sons, Inc., New York

Government of India, Department of Agriculture and Cooperation, Ministry of Agriculture.1993. Handbook of Seed Testing (Agrawal, P. K. ed.). New Delhi

Harrington, J.F.1973. Biochemical basis of seed longevity. Seed Science and Technology, $1: 453-461$

International Seed Testing Association, 1993. International Rules for Seed Testing. Seed Science and Technology, 13: 299-355

Justice, O.L. and Bass, L.N. 1978. Principle and practices of seed storage. Agricultural Handbook No. 506. U.S. Government Printing Office, Washington, DC

Monira, U.S., Amin, M. H. A., Marin, M. and Mamun, M.A.A. 2012. Effect of containers on seed quality of storage soybean seed. Bangladesh Reserach. Publication Journal, 7(4): 421-427. Retrieve

from http://www.bdresearchpublications.com/admin/journal/upload/09364/09364pdf

Ni, B. R. 1997. Seed coating, film coating and pelleting. In: Seed Industry and Agricultural Development, Chinese Association of Agricultural Sciences, DOA, Ministry of Agriculture, Beijing, China Agriculture Press, pp. 737-747

Omar, S. A. M. and Rahhal, M. M. H. 1993. Influence of fungicides on damping off disease and yield of soybean. Egyptian Journal of Agricultural Research, 71: 65-74

Rahman, M. M. K. and Rahman, G. M. M. 1997. Effect of container and length of storage on germination and seed-borne associated with jute seed. Bangladesh Journal of Plant Pathology, 13(1-2): 13-16

Raj, R.M., Kant, K. and Kulshreshta, D.D. 2002.Screening soybean cultivars for seed mycoflora and effect of thiram treatments. Seed Research, 30(1): 118-121

Sajad, S. 1980. The quality of seed forestry in Indonesia. Agriculture Institute Bogor.205p

Savitri, H., Suganakar Reddy, M. and Muralimohan Reddy, B. 1994.Effect of seed treatment with fungicides and insecticides on seed borne fungi, storage insect pest, seed viability and seedling vigour of sorghum. Seed Research, 22(2): 146-155

Savitri, H., Sugunakar Reddy, M. and Muralimohanreddy, B. 1998. Effect of seed treatment with fungicides and insecticides on seed borne fungi, storage insect pests,seed viability and seedling vigour of groundnut seed. Seed Research, 26(1): 62-72 
Scott, J. M. 1989.Seed coating treatments and their effects on plant establishment.Adv.Agron.32: 43-83

Sherin and Susan John. 2003. Seed film coating technology using polykote for maximizing the planting value, growth and productivity of maize. Cv. Col. M.Sc. (Agri.) Thesis, Tamil Nadu Agril. Univ., Coimbatore (India)

Tatipata, A. 2009. Effect of seed moisture content, packaging and storage period on mitochondria inner membrane of soybean seed. Journal of Agricultural Technology, 5(1): 51-64

Taylor, A.G., Allen, P.S., Benett, M.A., Bradford, K.J., Burris, J.S. and Misra, M.K.1998. Seed enhancements. Seed Science and Research, 8:245-256

Vanangamudi, K., Srimathi, P., Natarajan, N. and Bhaskaran, M. 2003, Current scenario of seed coating polymer.ICAR Short Course on Seed Hardening and Pelleting Technologies for Rainfed Garden Land Ecosystem, p. 80-100

Vertucci, C.W. and Roos, E.E. 1993. Theoretical basis of protocols for seed storage II.The influence of temperature on optimal moisture levels. Seed Science and Research, 3:201-213

Wilson, T. T. and Geneve,R.L. 2004.The impact of film coating on initial water uptake and imbibitional chilling injury in high and low vigour sh2sweet corn seeds. Seed Science and Technology, 32: 271-281 
Table 1: Effect of storage containers and seed coating on germination, seedling dry weight and seedling vigour index of soybean seed in storage

\begin{tabular}{|c|c|c|c|c|c|c|c|c|c|c|c|c|}
\hline \multirow[t]{3}{*}{ Treatment } & \multicolumn{4}{|c|}{ Germination (\%) } & \multicolumn{4}{|c|}{$\begin{array}{l}\text { Seedling dry weight } \\
(\mathrm{mg} \text { seedling })^{-}\end{array}$} & \multicolumn{4}{|c|}{ Seedling vigour Index } \\
\hline & \multicolumn{4}{|c|}{ Storage period (in months) } & \multicolumn{4}{|c|}{ Storage period (in months) } & \multicolumn{4}{|c|}{ Storage period (in months) } \\
\hline & 2 & 4 & 6 & 8 & 2 & 4 & 6 & 8 & 2 & 4 & 6 & 8 \\
\hline \multicolumn{13}{|l|}{ Storage containers } \\
\hline Clothe bag & 85.7 & 81.4 & 74.9 & 68.7 & 122.1 & 121.5 & 120.3 & 119.2 & 10464 & 9893 & 8992 & 8245 \\
\hline Polythene bag & 86.9 & 83.4 & 78.9 & 74.3 & 122.3 & 121.7 & 120.8 & 119.9 & 10622 & 10181 & 9539 & 8967 \\
\hline $\mathrm{SEm} \pm$ & 0.29 & 0.32 & 0.39 & 0.33 & 0.09 & 0.05 & 0.11 & 0.09 & 35 & 38 & 50 & 60 \\
\hline C.D. $(5 \%)$ & 0.8 & 0.9 & 1.1 & 1.0 & NS & 0.1 & 0.3 & 0.3 & 102 & 112 & 146 & 177 \\
\hline \multicolumn{13}{|c|}{ Seeds coating Treatments } \\
\hline $\mathrm{T} 0$ ( untreated control) & 84.8 & 79.8 & 73.3 & 66.2 & 121.8 & 121.2 & 120.0 & 118.7 & 10326 & 9677 & 8797 & 7854 \\
\hline $\begin{array}{l}\text { T1( Polymer coating } \\
@ 3 \mathrm{ml} \mathrm{kg}^{-1} \text { of seed) }\end{array}$ & 86.2 & 82.2 & 76.5 & 71.2 & 122.1 & 121.5 & 120.5 & 119.5 & 10518 & 9984 & 9218 & 8510 \\
\hline $\begin{array}{l}\text { T2( Flowable } \\
\text { Thiram@ } 2.4 \mathrm{ml} \mathrm{kg}^{-1} \text { of } \\
\text { seed) }\end{array}$ & 85.8 & 81.8 & 76.0 & 71.5 & 122.1 & 121.5 & 120.5 & 199.7 & 10479 & 9939 & 9160 & 8557 \\
\hline $\mathrm{T} 3(\mathrm{~T} 1+\mathrm{T} 2)$ & 86.8 & 84.0 & 78.2 & 72.7 & 122.3 & 121.9 & 120.7 & 199.7 & 10623 & 10240 & 9438 & 8868 \\
\hline $\begin{array}{l}\text { T4(Vitavax } 200 @ 2 \mathrm{~g} \\
\mathrm{~kg}^{-1} \text { of seed) }\end{array}$ & 86.3 & 82.2 & 77.5 & 72.0 & 122.1 & 121.5 & 120.5 & 199.5 & 10544 & 9987 & 9327 & 8771 \\
\hline $\mathrm{T} 5(\mathrm{~T} 1+\mathrm{T} 4)$ & 87.8 & 85.2 & 80.2 & 75.5 & 122.6 & 122.1 & 121.1 & 120.0 & 10768 & 10395 & 9652 & 9077 \\
\hline S.Em. \pm & 0.50 & 0.55 & 0.97 & 0.57 & 0.15 & 0.10 & 0.19 & 0.15 & 60 & 66 & 86 & 104 \\
\hline C.D. $(5 \%)$ & NS & 1.6 & 2.0 & 1.7 & 0.4 & 0.3 & 0.6 & 0.5 & 177 & 195 & 264 & 306 \\
\hline
\end{tabular}

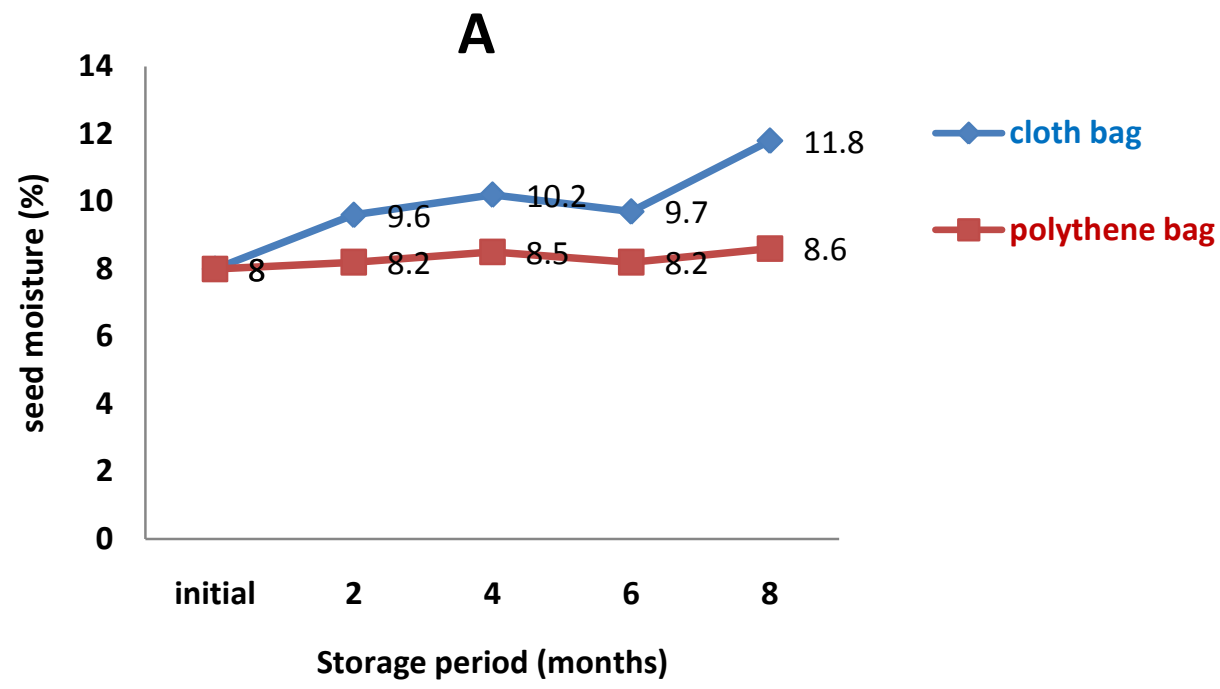




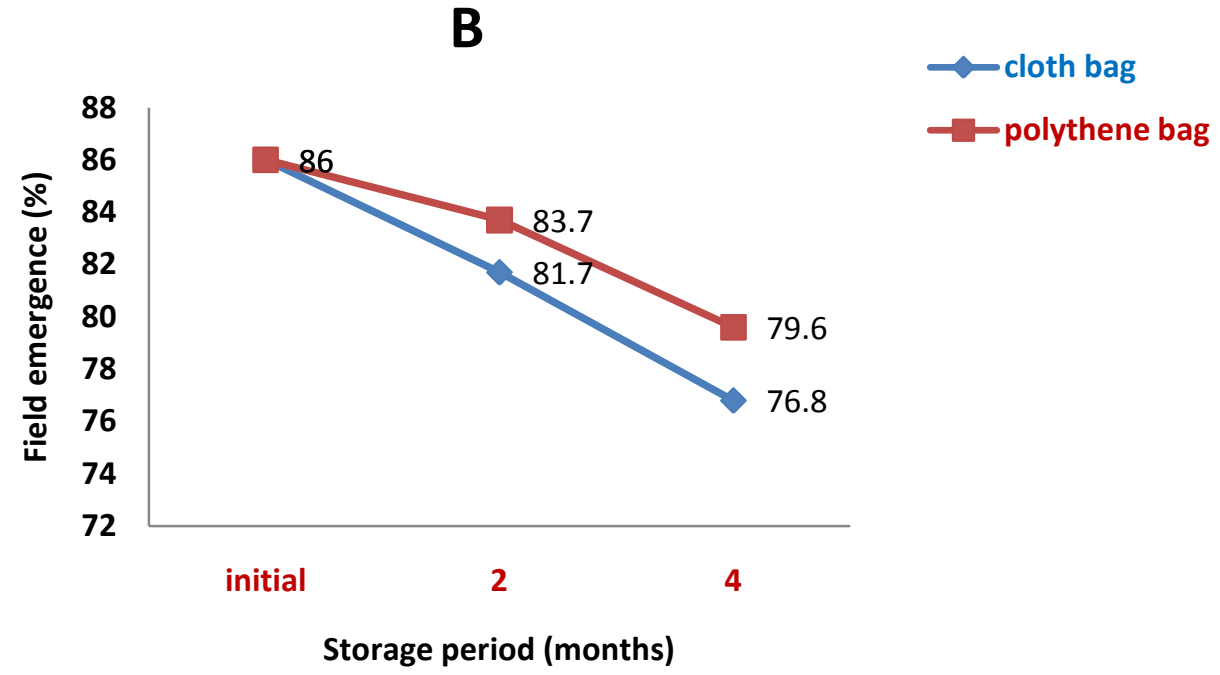

Figure 1: Effect of storage containers on seed moisture content (A) and field emergence (B) of soybean seed when stored at ambient storage

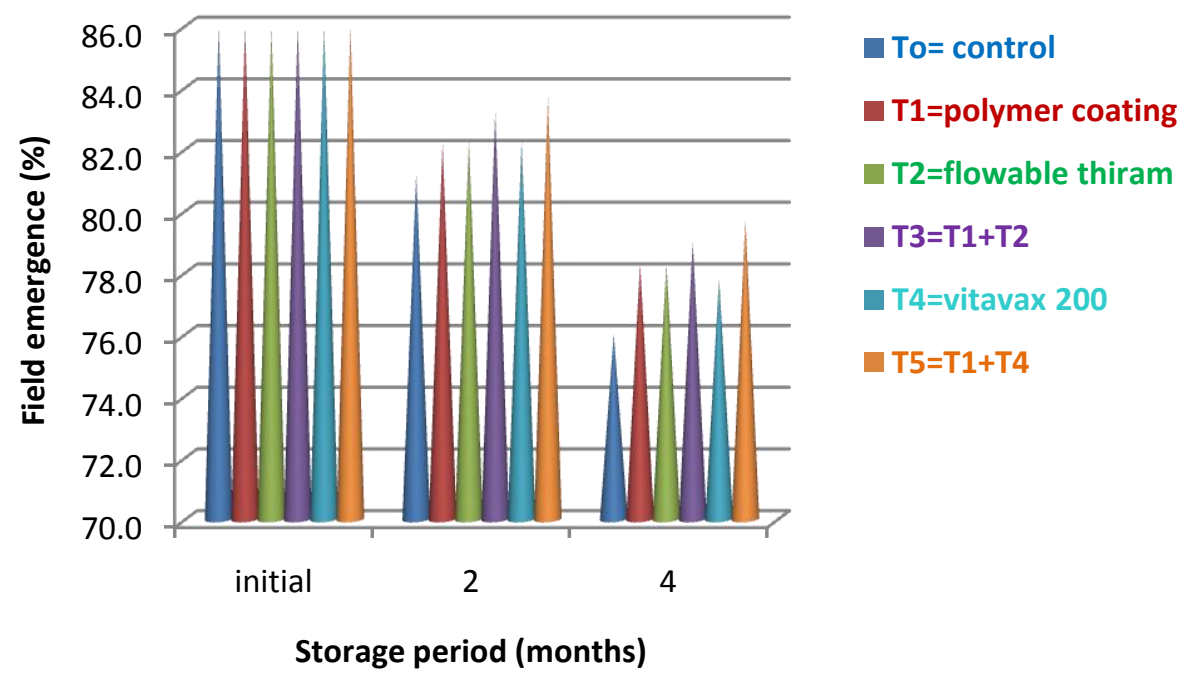

Figure 2: Effect of different seed coating on field emergence of soybean seed 